\title{
ALFRED HENRY STURTEVANT (November 21, 1891-April 6, 1970) STERLING EMERSON
}

\section{California Institute of Technology, Pasadena, California}

It would be difficult to overestimate the importance of Sturtevant's scientific contributions to the development of present-day genetic concepts. Even so I a m reluctant to attempt any such evaluation. Memories of a warm personal relationship extending over nearly fifty years distract me from strict objectivity. In any case, at the time (1913) of Sturtevant's earliest and perhaps most fundamental discovery (1) I was too young to appreciate its impact on contemporary biological thought. I doubt that a valid estimation of the worth of a particular contribution can be had without an understanding of the state of knowledge and interpretations generally held by scientists at the time. I do, however, vividly recall the extreme skepticism with which many biologists viewed genetic interpretations five, or even ten, years later, and I suspect that not all who accepted Mendelian interpretations could appreciate the importance of Sturtevant's deductions. It is fortunate for us that Sturtevant's penchant for accurate reporting overcame his innate modesty sufficiently to give something of his own assessment of the relation of his work to the particular time-in "A History of Genetics" (2), especially in the chapter titled "The Fly Room" which has been separately issued (3). It is also fortunate that a number of his most noteworthy publications were reissued in a single volume in commemoration of his seventieth birthday (4). As pointed out by a number of reviewers of this volume, some of whom were Sturtevant's contemporaries, it is remarkable that a single individual should have made so many fundamental contributions. Among the remarks by J. B. S. Haldane (5), known for his critical, even caustic, reviews is:

On looking back on his papers, a biologist is often liable to feel that he could have done the work very much better 20 years later. Because this is not so for Sturtevant's most important papers, they are classics, which any student of genetics may read with profit, and are rightly seprinted. ... And students may be told 'Even if you don't discover anything as important as Sturtevant did, at least try to express yourself as clearly.'

Sturtevant's 1913 paper "The linear arrangement of six sex-linked factors in Drosophila as shown by their mode of association" is fairly widely considered to be his most important single contribution. In it he developed the three-point test for determining gene order which also, and more impor- 
tantly, constituted an algebraic proof of linearity. ${ }^{1}$ I certainly did not appreciate the full implication of this work until $\mathrm{H}$. J. Muller, in an address at Cold Spring Harbor in the summer of 1921, described the excitement in the fly room one morning when "that young boy Sturtevant" propounded his proof of linearity. Sturtevant's own account (3) gives only the prelude to this announcement: "I went home, and spent most of the night (to the neglect of my undergraduate homework) in producing the first chromosome map, including the linked genes $y, w, v, m$, and $r$, in the order, and approximately the relative spacing, as they still appear on the standard maps." There is some indication that Sturtevant himself considered this his most important contribution to science. On an occasion, years ago, when the two of us were dissecting the character of a colleague, he suggested that I should give some consideration to the effect upon a young scientist of the knowledge that his very first piece of work was quite sure to be better than anything he could do later. Even if Sturtevant did believe himself to be in that position it did not prevent him from turning out numerous contributions of a quality others would be happy to equal.

I began to become acquainted with Sturtevant in the summer of 1922 (in the interim between my own undergraduate and graduate studies). We were in neighboring labs in the Marine Biological Laboratories at Woods Hole. Sturtevant even then budgeted his time so that his work with Drosophila crosses was completed in the mornings, leaving the afternoons for other occupations-in the library, keeping up with the current literature in a broad spectrum of areas; in the field, collecting ants and acalyptarate Diptera, but also observing all kinds of other things, as a naturalist should; or back in the lab working up his collections. I was fortunate to be able to accompany him on a number of these collecting trips and, while I was technically a botanist, he a zoologist, he knew the flora much better than I. As the son of a professor, I was never overawed by rank in the academic profession, but it was an unexpected pleasure to have Sturtevant treat one so much his junior as his equal. This attitude towards younger biologists was again evident when I visited him at Columbia a few years later (in the fall of 1926) and, knowing I was working with Oenothera, he told me how he had overlooked Renner's papers at the time the "Mechanism" (6) was written, and how he now thought that Renner was making some sense out of the complicated genetic behavior of Oenothera. He also explained how he

${ }^{1}$ If three genes are in linear order and recombination occurs by crossing over between genes, one of the three pairs of complementary crossovers can result only from double crossing over and, if crossing over in one region occurs independently of that in the other, the frequency of double crossing over, being a fraction of a fraction, must be less than the frequencies of total crossing over in either region. And, if total observed crossovers in each separate region are less frequent than fifty percent, observed double crossovers should be less frequent than either class of single crossovers. 
worked out the unequal crossing over at the Bar locus (7) by an extremely neat set of experiments - with which he was obviously pleased.

Sturtevant had a very good memory and could al most instantly recognize the relationship of a new observation to facts already known. I first saw this reaction occur at the A.A.A.S. meetings in Philadelphia in 1926. A. F. Blakeslee read a paper by John Belling (who was ill) in which end-to-end associations of a number of Datura chromosomes into rings was interpreted to have resulted from successive reciprocal translocations. Sturtevant got hold of Ralph Cleland, who had established the chromosome ring structures of several Oenothera species, found a small room where we could be private, and proceeded to see if Belling's interpretation would fit the ring structures in Oenothera species hybrids then being studied by Cleland. It seemed to work, but the data were still too meagre to constitute proof. Sturtevant then started his own cytogenetic studies of Oenothera and, not long after we became settled in Pasadena, it was possible to establish the homologies between species of twelve of the fourteen chromosome ends (8).

Pre-molecular genetics was still an absorbing subject at the time that Thomas Hunt Morgan established the Biology Division at Caltech and for at least a dozen years after that. Mutation induction by X-ray and ultraviolet irradiation had just been discovered, followed shortly by the cytological mapping of chromosome breaks on the salivary gland chromosomes of Drosophila; it was still the heyday of cytogenetics and comparative genetics of related species; population genetics was being increasingly attacked by both field studies and laboratory experiments; and so on-some of us even expected the momentary solution of the mechanism of crossing over. Furthermore, Caltech was a world center of genetic activity during this period. In addition to the group assembled by Morgan (Sturtevant, C. B. Bridges, E. G. Anderson, S. Emerson and, a year later, Th. Dobzhansky who was a fellow of the Rockefeller Foundation the first year) there was a constant stream of visiting research workers, European (mostly fellows of the Rockefeller Foundation) as well as American (mostly fellows of the National Research Council, a recent innovation in biology). These included, more-or-less in order of appearance: Marcus Rhoades, G. D. Karpechneko, A. R. Jebrak, G. W. Beadle, C. R. Burnham, W. E. Lammerts, Barbara McClintock, B. P. Kaufman, C. D. Darlington, Curt Stern, Boris Ephrussi, Jacques Monod, M. D. Sweitzer, P. T. Ives, Hans Bauer, D. G. Catcheside, Warren D. Spencer, Sewall Wright, John B. Buck, Maurice Whittinghill, G. H. M. Gottschewski, P. C. Koller, Kenneth Mather, Max Delbrück, John Raper, and Herman Kalckar. These "visitors" added a great deal to the activities then going on and most of them seemed to feel that they also had gained by the experience. If they could be polled, most would say that their contacts with Sturtevant had been their most rewarding experience.

Sturtevant continued to work with Drosophila throughout his career, but always with one or more side-lines to which he contributed in a serious way, as can be seen from his published papers (4). His interest in the tax- 
onomy and behavior of ants and the Diptera continued throughout; his active interest in Oenothera genetics lasted only until the major puzzles had been solved; after this he hybridized iris, perhaps partly because he liked them, but also to give him first-hand experience with the genetics of polyploids.

Sturtevant kept up with the advances towards present day molecular genetics and made valuable suggestions relating both to methodology and interpretation, though he never worked directly in these areas. Early on, he did start to use immunological methods, but soon gave up the effort. My own interpretation is that he was happy only when working with organisms, and not at all when it was necessary to make up solutions and experiment with them. He truly liked to work with Drosophila, with which he was extraordinarily adept. He was the only Drosophila worker I have known who transferred flies from one bottle to another without banging. For him it was sufficient to hold two bottles mouth-to-mouth, with the receiving bottle directed towards the window and upwards at a forty-five degree angle and the flies would begin a mass migration into the new bottle. I wonder how many others have tried as often as I to induce the same phenomenon. I have found it difficult not to believe that the flies liked Sturt and wished to please him.

\section{LITERATURE CITED}

1. Sturtevant, A. H. 1913. The linear arrangement of six sex-linked factors in Drosophila, as shown by their mode of association. J. Exp. Zool. 14:43-59

2. Sturtevant, A. H. 1965. A Hislory of Genetics. Harper and Row, New York, 165 pp.

3. Sturtevant, A. H. 1965. The "fly room." Am. Sci. 53:303-07

4. Sturtevant, A. H. 1961. Genetics and Evolution, Selected Papers of A. H. Sturtevant. Ed. E. B. Lewis. W. H. Freeman, San Francisco \& London, 334 pp.

5. Haldane, J. B. S. 1962 . Monumentum aere perennius. J. Genet. 58:145-46

6. Morgan, T. H., Sturtevant, A. H., Muller, H. J., Bridges, C. B. 1923. Revised Edition. H. Holt, New York

7. Sturtevant, A. H. 1925. The effects of unequal crossing over at the bar locus in Drosophila. Genetics 10: 117-47

8. Emerson, S., Sturtevant, A. H. 1931. Genetic and cytological studies on Oenothera. III. The translocation interpretation. $Z$. Vererbungslehre $59: 395-419$ 